$\mathrm{Nu}$ het voorhanden hebben van een boksbeugel een strafbaar feit oplevert, zou overigens onttrekking van de boksbeugel aan het verkeer bij afzonderlijke beschikking op de voet van artikel $36 \mathrm{~b}$ lid 1 onder $4^{\circ}$ jo. artikel $36 \mathrm{c}$ onder $2^{\circ} \mathrm{Sr}$ tot de mogelijkheden kunnen behoren.

\section{NTS 2020/17}

\section{HR 1 oktober 2019, 19/00827, ECLI:NL:HR:} 2019:1472

\author{
Cassatie in belang der met. Beschikking Rb inhoudende \\ toemijzing verzoek ex art. $36 \mathrm{~Sv}$ tot verklaring dat zaak \\ geëindigd
}

\section{Aantekening redactie}

Volgens artikel $36 \mathrm{~Sv}$ 'kan het gerecht in feitelijken aanleg, voor hetwelk de zaak het laatst werd vervolgd, op het verzoek van den verdachte of op voordracht van de rechter-commissaris op de voet van artikel 180, verklaren dat de zaak geëindigd is indien een vervolging niet wordt voortgezet'.

In deze cassatie in het belang der wet werd een drietal vragen betreffende de uitleg van artikel $36 \mathrm{~Sv}$ voorgelegd aan de Hoge Raad:

'1. Op welk moment neemt "vervolging" a.b.i. art. $36 \mathrm{~Sv}$ aanvang?

2. Kan verklaring ex art. $36 \mathrm{~Sv}$ dat zaak is geëindigd worden gegeven wanneer onderzoek ttz. aanvang heeft genomen?

3. Kan overschrijding van redelijke termijn ex art. 6.1 EVRM grond bieden voor geven van verklaring dat zaak is geëindigd?'

Het betrof hier een beschikking van Rechtbank NoordNederland, zittingsplaats Groningen, van 23 mei 2018 waarbij een verzoek ex artikel $36 \mathrm{~Sv}$ tot verklaring dat de zaak geëindigd is, is toegewezen. In die beschikking heeft de rechtbank het verzoek van de verdachte om te verklaren dat de zaak is geëindigd ex artikel $36 \mathrm{~Sv}$, toegewezen op een moment waarop het onderzoek ter terechtzitting al was aangevangen. De vraag was of dat rechtens kon. Naast deze vraag speelden in de rechtspraktijk nog twee andere vragen met betrekking tot de uitleg van artikel $36 \mathrm{~Sv}$. De eerste was wat onder 'vervolging' in de zin van artikel $36 \mathrm{~Sv}$ moet worden verstaan en meer in het bijzonder of het artikel toepassing kan vinden in gevallen waarin nog geen rechter op vordering van de officier van justitie in de zaak is betrokken. De tweede was aan de hand van welke maatstaf moet worden beoordeeld of de zaak 'niet wordt voortgezet' in de zin van het artikel. Meer in het bijzonder was de vraag of de overschrijding van de redelijke termijn grond kan opleveren om te verklaren dat de zaak geëindigd is. Ook deze twee vragen werden in de vordering aan de Hoge Raad ter beantwoording voorgelegd. Zij raken namelijk, net als de vraag die in de bestreden beschikking primair aan de orde was, de functie die aan artikel $36 \mathrm{~Sv}$ in de hedendaagse strafrechtspleging toekomt. De antwoorden van de Hoge Raad op deze vragen - die er overigens toe leidden dat het oordeel van de rechtbank getuigt van een onjuiste rechtsopvatting ${ }^{13}$ - worden hieronder integraal weergegeven:

4.3

Het in art. $36 \mathrm{~Sv}$ bedoelde verzoek kan worden gedaan ingeval van "vervolging" van een zaak. Naar hedendaagse rechtsopvatting vangt de vervolging als bedoeld in art. 36, eerste lid, Sv aan op het moment dat vanwege de Nederlandse Staat jegens de betrokkene een handeling is verricht waaraan deze in redelijkheid de verwachting kan ontlenen dat tegen hem ter zake van een bepaald strafbaar feit door het openbaar ministerie een strafvervolging zal worden ingesteld. Vanaf dat moment - en niet eerst vanaf het moment dat het openbaar ministerie de strafrechter betrekt in de strafzaak - kan de verdachte immers belang hebben bij het inroepen van het oordeel van de rechter omtrent het geëindigd zijn van de zaak.

4.4

In de systematiek van het Wetboek van Strafvordering ligt besloten - zoals onder meer tot uitdrukking komt in het voorschrift van art. 266, eerste lid, Sv dat ertoe strekt dat de officier van justitie de dagvaarding niet meer kan intrekken zodra het onderzoek ter terechtzitting is aangevangen - dat, nadat het onderzoek ter terechtzitting is aanvangen, de procedure wordt voortgezet totdat een einduitspraak is gegeven door de zittingsrechter. Daarmee verhoudt zich niet dat een verklaring dat de zaak is geëindigd, wordt verzocht en gegeven op het moment dat het onderzoek ter terechtzitting een aanvang heeft genomen en door de zittingsrechter nog niet onherroepelijk einduitspraak is gedaan. In die situatie dient de verdachte in het verzoek als bedoeld in art. $36 \mathrm{~Sv}$ niet-ontvankelijk te worden verklaard.

Onder omstandigheden kan een verdachte wel worden ontvangen in een verzoek als bedoeld in art. 36 $\mathrm{Sv}$ nadat de einduitspraak onherroepelijk is geworden. Dat kan onder meer het geval zijn indien bij de einduitspraak de onbevoegdheid van de rechter of de nietigheid van de dagvaarding is uitgesproken.

4.5

13. De rechtbank had de verdachte dus niet-ontvankelijk behoren te verklaren in het verzoek als bedoeld in art. $36 \mathrm{~Sv}$. 
In het geval dat het onderzoek ter terechtzitting is aangevangen en vervolgens voor onbepaalde tijd wordt geschorst, terwijl het openbaar ministerie, nadat de oorzaak van de schorsing is vervallen, nalaat het onderzoek ter terechtzitting te doen hervatten door, kort gezegd, het opnieuw aanbrengen van de zaak op een nadere terechtzitting, vormt dat nalaten gelet op wat onder 4.4 is overwogen - geen grond warop een verklaring als bedoeld in art. $36 \mathrm{~Sv}$ kan worden gegeven dat de zaak is geëindigd. Geen rechtsregel staat er echter aan in de weg dat de verdachte zich in dat geval wendt tot de voorzitter van het gerecht waar de zaak dient, met het verzoek de dag van de nadere terechtzitting te bepalen.

\subsection{1}

Overschrijding van de redelijke termijn kan aanleiding geven tot strafvermindering, maar leidt niet tot de niet-ontvankelijkverklaring van het openbaar ministerie in de strafvervolging, ook niet in uitzonderlijke gevallen (vgl. HR 17 juni 2008, ECLI:NL:HR:2008:BD2578, rov. 3.21-3.23). Dat staat - gelet op het rechtsgevolg dat art. 255, eerste lid, Sv verbindt aan de beschikking dat de zaak is geëindigd, inhoudende dat de verdachte alleen bij het bekend worden van nieuwe bezwaren opnieuw in rechte kan worden betrokken ter zake van hetzelfde feit - tevens eraan in de weg dat de rechter op de voet van art. $36 \mathrm{~Sv}$ verklaart dat de zaak is geëindigd op de grond dat het recht op berechting binnen een redelijke termijn als bedoeld in art. 6, eerste lid, EVRM is geschonden. Dat is niet anders indien aan een verzoek als bedoeld in art. $36 \mathrm{~Sv}$ (mede) ten grondslag is gelegd dat de overschrijding van de redelijke termijn tevens een inbreuk op andere verdedigingsrechten tot gevolg heeft, bijvoorbeeld waar het de mogelijkheid betreft van het bieden van een behoorlijke en effectieve gelegenheid tot ondervraging. Het is aan de zittingsrechter en niet aan de rechter die oordeelt over het verzoek als bedoeld in art. $36 \mathrm{~Sv}$, te bepalen of van zo'n inbreuk sprake is en zo ja, of dat in de concrete omstandigheden van het geval ook betekent dat zich een schending van art. 6 EVRM voordoet waaraan bij de berechting van de zaak gevolgen dienen te worden verbonden (vgl. HR 13 september 2016, ECLI:NL:HR:2016:2059).

\subsection{2}

Grond voor het geven van een verklaring dat de zaak is geëindigd kan de rechter onder meer wel vinden in de omstandigheid dat niet of nauwelijks (meer) activiteiten worden verricht in het strafrechtelijk onderzoek tegen de verdachte en het daarnaast redelijkerwijs niet valt te verwachten dat het openbaar ministerie tegen de verdachte strafvervolging zal instellen of voortzetten, in het bijzonder door jegens de verdachte een strafbeschikking uit te vaardigen of hem te dagvaarden, zonder dat het openbaar ministerie daaromtrent zelf al duidelijkheid heeft verschaft aan de verdachte in de vorm van een (sepot)beslissing als bedoeld in art. 167 of $242 \mathrm{~Sv}$ dan wel anderszins. Mede vanwege het door art. 255, eerste lid, Sv aan de verklaring dat de zaak is geëindigd verbonden rechtsgevolg, betreft het hier een tot terughoudendheid nopende maatstaf. Bij de toepassing daarvan kan de rechter in voorkomende gevallen onder meer in aanmerking nemen dat het openbaar ministerie nalatig is geweest gevolg te geven aan een door de rechter-commissaris op grond van art. 180, derde lid, Sv gestelde termijn tot beëindiging van het opsporingsonderzoek, dan wel dat, niettegenstaande een aanhouding op de beslissing van het verzoek als bedoeld in art. 36, tweede lid, Sv, geen nadere activiteiten van het openbaar ministerie met betrekking tot het tegen de verdachte gerichte onderzoek of de strafvervolging van de verdachte zijn gebleken.'

\section{NTS 2020/18}

HR 1 oktober 2019, 18/00057, ECLI:NL:HR:

2019:1481

\begin{abstract}
Medeplegen voorbereidingshandelingen hennepteelt door in bedrijfspand armaturen, assimilatielampen, transformatoren en koolstoffilters voorhanden te hebben, art. 11a Opiummet. Voorhanden hebben stoffen en voormerpen hennepkmekerij bij ontmanteling daarvan nog 'bestemd tot' beroepsmatige en / of grootschalige hennepteelt?
\end{abstract}

\section{Aantekening redactie}

In artikel 11a Opiumwet is - kort gezegd - strafbaar gesteld het verrichten van handelingen ter voorbereiding of vergemakkelijking van illegale hennepteelt ('growshopverbod'). ${ }^{14}$ Ondernemingen zoals growshops hebben zich toegelegd op handelingen ter voorbereiding of vergemakkelijking van illegale hennepteelt. Bedrijfsactiviteiten die zich toeleggen op deze handelingen zijn sinds 2015 strafbaar. Voor strafbaarheid is vereist dat de aangetroffen stoffen en voorwerpen zijn 'bestemd tot' beroepsmatige en/of grootschalige hennepteelt. In de onderhavige zaak warden weliswaar armaturen, assimilatielampen, transformatoren en koolstoffilters (overdui-

'Hij die stoffen of voorwerpen bereidt, bewerkt, verwerkt, te koop aanbiedt, verkoopt, aflevert, verstrekt, vervoert, vervaardigt of voorhanden heeft dan wel vervoermiddelen, ruimten, gelden of andere betaalmiddelen voorhanden heeft of gegevens voorhanden heeft, waarvan hij weet of ernstige reden heeft om te vermoeden dat zij bestemd zijn tot het plegen van een van de in artikel 11, derde en vijfde lid, strafbaar gestelde feiten, wordt gestraft met gevangenisstraf van ten hoogste drie jaar of geldboete van de vijfde categorie.' 